\title{
Grammaticalization in Emirati Arabic
}

\author{
Najib Ismail Jarad \\ University of Sharjah \\ njarad@sharjah.ac.ae
}

\begin{abstract}
This paper is concerned with the process of language change whereby lexical items and constructions, in specific contexts, come to serve new grammatical functions. Emirati Arabic provides us with a wide range of grammaticalization phenomena. The aim of this paper is twofold: to shed light on the basic concepts relating to grammaticalization phenomena and to examine the grammaticalization of a number of constructions in Emirati Arabic, investigating their formation and the changes in their functions. The development of these grammatical constructions follows a grammaticalization pathway identified for a wide range of linguistic items cross-linguistically.
\end{abstract}

\section{Keywords}

Emirati Arabic, grammaticalization, volition verb, genitive exponent, reflexive pronoun, subordinate conjunction

\section{Résumé}

Cet article s'intéresse au processus du changement de la langue dans laquelle des éléments et des constructions lexicales, dans des contextes spécifiques, viennent assurer de nouvelles fonctions grammaticales. L'arabe émirati nous offre un large éventail

* This paper was presented at the 3rd International Conference on "Language, Linguistics, Literature and Translation: Connecting the Dots in a Globalized World" in 2016, Sultan Qaboos University, Muscat, Oman. I would like to thank the audience for their comments and suggestions. I am also extremely grateful for the insightful comments of three anonymous reviewers whose input has greatly improved this paper. Needless to say, all remaining errors and shortcomings are my own responsibility. 
de phénomènes de grammaticalisation. L'objectif de cet article est double : mettre en lumière les concepts fondamentaux relatifs au phénomène de grammaticalisation et examiner la grammaticalisation d'un certain nombre de constructions en arabe émirati, en étudiant leur formation et les changements dans leurs fonctions. Le développement de ces constructions grammaticales suit un processus de grammaticalisation identifié pour un large éventail d'éléments linguistiques.

\section{Mots clefs}

Arabe émirati, grammaticalisation, verbe de volonté, génitif, pronom réfléchi, conjonction subordonnée

\section{Introduction}

This study deals with some aspects of language change in Emirati Arabic. Given the dynamic nature of language, language change, according to Bybee, is "an integral part of language and an inevitable outcome of language use." Language is always evolving and adapting to the needs of its users. Changes are inherent in language and reflect progress rather than decay.

Cross-linguistic research on grammatical categories has made it possible to establish and predict regular evolution pathways. The predictability of the rise of grammatical categories is based on the principle that lexical items (e.g. nouns, verbs, adjectives, etc.) in specific contexts attain a grammatical status (e.g. auxiliaries, connectives, clitics, etc.). The evolution pathways are often convergent, which means one type of grammatical marker can be shown to develop from a number of distinct lexical sources. Therefore, future markers - in addition to evolving from motion verbs such as "go" and "come" - also evolve from verbs of volition (e.g. Greek tha $<$ thelo hina "I wish that," Romanian voi $<$ Latin velle "to wish," Bulgarian ŝte < "I want that," Swahili -ta $<$ taka "want"). ${ }^{3}$

1 Joan Bybee, Language Change, Cambridge, Cambridge University Press, 2015, p. 10.

2 See Ian Roberts and Anna Roussou, Syntactic Change: A Minimalist Approach to Grammaticalization, Cambridge, Cambridge University Press ("Cambridge studies in linguistics", 100), 2003, p. 58-71.

3 See Bybee, Joan and William Pagluica, "The Evolution of Future Meaning”, in Papers from the 7 th International Conference on Historical Linguistics, eds. Anna Ramat, Onofrio Carruba Giacalone and Giuliano Bernini, Amsterdam-Philadelphia, John Benjamins ("Amsterdam studies in the theory and history of linguistic science. Series 4, Current issues in linguistic 
When a lexical item in specific contexts attains a grammatical status through the process of grammaticalization, it undergoes structural, semantic, and phonological change. For example, the English modal will developed out of a verb of desire (Old English willan "want"). The old ("She makes you will your own destruction," George Bernard Shaw; "John can pass the test if he wills it") and the new meanings exist side by side ("The results of the test will appear later"). The degree of grammaticalization of the same lexical item is subject to both regional and social variation, i.e. the item may vary from one variety to another, both geographically and socially. ${ }^{4}$

The aim of this paper is to examine the grammaticalization of a number of constructions in Emirati Arabic, investigating their formation, as well as the changes in their functions. Emirati Arabic, a variety of Gulf Arabic, is the variety used in informal situations by the sedentary native people of the United Arab Emirates (Abu Dhabi, Dubai, Sharjah, Ajman, Umm al-Quwain, Ras alKhaima, and Fujaira). It should be highlighted here that there is a high degree of mutual intelligibility among these Emirates; minor phonological and lexical differences do exist. ${ }^{5}$ Synchronic documentation of this variety is scanty. The googlization of "Emirati Arabic" yielded two results: one doctoral dissertation titled Morphology of United Arab Emirates Arabic, Dubai Dialect by Benjamin Theodore Hoffiz (1995), ${ }^{6}$ and an MA thesis titled A Phonological Description of Emirati Arabic written by Hana al-Ameri (2009). ${ }^{7}$ There is only one grammar reference on Emirati Arabic: A Short Reference Grammar of Gulf Arabic (1977) by Hamdi Qafisheh. The title refers to Gulf Arabic but the book is actually based on the dialect of Abu Dhabi, in the United Arab Emirates. It presents an explicit outline of the phonology, morphology, and syntax of this variety. Emirati Arabic is also sporadically mentioned in the four-volume Encyclopedia of Arabic Language and Linguistics as part of Gulf Arabic.

theory", 48), 1987, p. 112-114. See also Joan Bybee, Revere Perkins and William Pagliuca, The Evolution of Grammar: Tense, Aspect, and Modality in the Languages of the World, ChicagoLondon, University of Chicago Press, 1994, p. 240 and $53 \mathrm{ff}$.

4 For detailed discussion of the development of will/shall, see, among others: Joan Bybee, Language, Usage and Cognition, Cambridge-New York, Cambridge University Press, 2010, and Rena Torres Cacoullos and James A. Walker, "The Present of the English Future: Grammatical Variation and Collocations in Discourse," Language, 85/2 (2009), p. 321-354.

5 Due to the limited scope of the present study and the lack of sufficient data, the differences between Sedentary and Bedouin Emirati Arabic dialects will not be attempted.

6 This dissertation is available at http://arizona.openrepository.com/arizona/handle/10150/ 187179, accessed 26/07/2017.

7 This thesis is available at http://docs.lib.purdue.edu/dissertations/AAI1475967/, accessed 26/07/2017. 
The significance of the present study lies in the fact that it provides a description of some structures in an understudied Arabic variety. It also provides support for the mechanisms involved in grammaticalization and adds to the growing literature of studies of grammaticalization on other Arabic spoken varieties. It is hoped that the present study would contribute to future studies of Gulf Arabic, particularly the variety of Arabic spoken in the United Arab Emirates. A study like this might generate more interest in Emirati Arabic in general and might also pique the curiosity of scholars who work on language change.

The remainder of the paper is organized as follows. First, we provide an overview of some major concepts of the theoretical framework: grammaticalization. Next, the paper presents the methods of data collection and analysis. The main body of the paper provides brief description and analysis of four examples of grammaticalization in Emirati Arabic: volitional verb > future marker, noun $>$ subordinate conjunction, noun $>$ reflexive pronoun and, finally, noun $>$ possessive exponent.

Grammaticalization is present in all languages at all times and is a type of innovation and linguistic change. Although the use of the term grammaticalization goes back to Meillet in $1912,{ }^{8}$ studies in this field did not flourish until the beginning of the 1980's, and the application of this term to the study of Arabic is even more recent. ${ }^{9}$ It is not my purpose here to give a full introduction to grammaticalization..$^{10}$ However, it is useful here to explain some of the basic

8 Antoine Meillet, Linguistique historique et linguistique générale, Paris, Librairie ancienne Honoré Champion ("Collection linguistique", 8), 1921, p. 130-148.

9 Balkees Al-Najjar, "Grammaticalization of Lexical Markers in Kuwaiti Arabic," Folia Linguistica, 25 (1991), p. 665-674; Mohsen Esseesy, “Grammaticalization,” in Encyclopedia of Arabic Language and Linguistics, ed. Kees Versteegh, Leiden-Boston, Brill, 2007, II, p. 191-198; Mohsen Esseesy, Grammaticalization of Arabic Prepositions and Subordinators: A Corpus-based Study, Leiden-Boston, Brill ("Studies in Semitic languages and linguistics", 59), 2010.

$10 \quad$ For more details, see the following works: Bernd Heine and Tania Kuteva, World Lexicon of Grammaticalization, New York, Cambridge University Press, 2002; id., The Genesis of Grammar: A Reconstruction, Oxford-New York, Oxford University Press ("Studies in the evolution of language", 9), 2007; Christian Lehmann, "Theory and Method in Grammaticalization," Zeitschrift für Germanische Linguistik, 32/2 (2004), p. 152-187; Bernd Heine and Heiko Narrog (eds), "Introduction," in The Oxford Handbook of Grammaticalization, 
concepts relating to grammaticalization phenomena that will be relevant to the present investigation.

Grammaticalization, according to Hopper and Traugott, ${ }^{11}$ is "that part of the study of language change that is concerned with such questions as how lexical items and constructions come in certain linguistic contexts to serve grammatical functions or how grammatical items develop new grammatical functions" (1). For example, the English verb "to go" originally denoted only motion in space (e.g. "I am going to the store"), but has acquired an additional function as an auxiliary in a verb phrase expressing the immediate future (e.g. "I am going to wash my car"). Therefore, the English verb phrase "be going to" can be said to have grammaticalized from a main verb (a lexical word) into an auxiliary verb (a function word). In other words, lexical items undergo the following sequence of changes: ${ }^{12}$

$$
\text { content item } \rightarrow \text { grammatical word } \rightarrow \text { clitic } \rightarrow \text { inflectional affix }
$$

The movement of a segment down this cline is largely considered to be unidirectional and accompanied by: ${ }^{13}$
a. extension (use in new contexts and increasing frequency);
b. desemanticization ("semantic bleaching")—-loss in meaning content;
c. decategorialization (loss in morphosyntactic properties);
d. phonetic reduction ("erosion")—-loss in phonetic substance.

eds Bernd Heine and Heiko Narrog, Oxford-New York, Oxford University Press ("Oxford handbooks in linguistics"), 2011; Elizabeth Closs Traugott and Greame Trousdale, "Introduction", in Gradience, Gradualness and Grammaticalization, eds Elizabeth Closs Traugott and Greame Trousdale, Amsterdam-Philadelphia, John Benjamin ("Typological studies in language", 9o), 2010; id., Constructionalization and Constructional Changes, Oxford, Oxford University Press ("Oxford studies in diachronic and historical linguistics", 6), 2013; Sylvie Hancil and Ekkehard König, Grammaticalization: Theory and Data, AmsterdamPhiladelphia, John Benjamins ("Studies in language companion series", 162), 2014; Elizabeth Closs Traugott and Richard B. Dasher, Regularity in Semantic Change, Cambridge, Cambridge University Press ("Cambridge studies in linguistics", 96), 2002; Andrew Smith, Graeme Trousdale and Richard Waltereit, New Directions in Grammaticalization Research, Amsterdam-Philadelphia, John Benjamins ("Studies in language companion series", 166), 2015 .

11 Paul J. Hopper and Elizabeth Closs Traugott, Grammaticalization, Cambridge, Cambridge University Press, 2003.

12 Ibid., p. 7.

13 Heine and Kuteva, World Lexicon of Grammaticalization, p. 2. 
For example, English will which originally meant "want" or "desire" lost its sense of "want" or "desire" and was grammaticalized as a marker of futurity. This means that will was decategorialized as a modal auxiliary and was later phonetically reduced, as in "'ll," "she'll," and so on. ${ }^{14}$ Through the gradual changes in the steps along the path of grammaticalization, a linguistic expression is decategorized from an open-class category into a closed-class item. That is, grammaticalization proceeds from concrete to abstract but not vice versa, and from the more linguistically autonomous to the more linguistically dependent.

Paul J. Hopper and Elizabeth Closs Traugott indicated that grammaticalization is "hypothesized to be prototypically a unidirectional phenomenon."15 It is interesting to note that these unidirectional tendencies are not language specific but are governed by cross-linguistically or even universally valid principles. ${ }^{16}$ For example, certain types of words may develop into grammatical morphemes, but grammatical morphemes do not tend to develop into words. There is a tendency for personal pronouns to become clitics and then verbal affixes, but not for verbal affixes to become personal pronouns. ${ }^{17}$

At first sight, there seems to be a problem with the cline of grammaticalization because the generalizations it involves do not seem to hold. For example, a change from lexical to grammatical status may not trigger phonetic reduction by itself. However, the hypothesis of unidirectionality does not mean that grammatical entities inevitably move through all stages of development, or that these cannot fall into disuse at any stage along the way, but simply that changes tend to occur in a predictable direction. ${ }^{18}$

14 For more details, see Ilse Wischer, "Markers of futurity in Old English and the grammaticalization of shall and will," Studia Anglica Posnaniensia, 42 (2006), p. 165-179.

15 Hopper and Traugott, Grammaticalization, p. 99.

16 Providing evidence from several languages, Bybee, Perkins and Pagliuca show that verbs denoting "want" or "desire" are common sources of future markers. See Bybee, Perkins and Pagliuca, The Evolution of Grammar.

17 Hopper and Traugott, Grammaticalization, p. 15.

18 For criticism of the hypothesis of unidirectionality, see the special issue of Language Sciences, 23/2-3 (2001). Although some instances of change in the opposite direction, viz. from abstract to concrete have been identified, such cases are far fewer than the numerous examples concerning the unidirectionality hypothesis (see Martin Haspelmath, "Why is Grammaticalization Irreversible?," Linguistics, 37/6 (1999), p. 1043-1068; Martin Haspelmath, "On Directionality in Language Change with Particular Reference to Grammaticalization," in Up and Down the Cline: The Nature of Grammaticalization, eds Olga Fischer, Muriel Norde and Harry Perridon, Amsterdam-Philadelphia, John Benjamins (“Typological studies in language", 59), 2004, p. 17-44. 
Grammaticalization involves semantic, syntactic, and phonological changes. First, the lexical item undergoes a shift in meaning or extension of meaning to new contexts, followed in later stages by a weakening or loss of its original semantic content (also called "bleaching"). Second, the lexical item undergoes syntactic change or "decategorialization" (i.e. loss of syntactic properties of the category it belonged to before it grammaticalized), which might be accompanied by phonological reduction..$^{19}$ According to Heine and Kuteva, ${ }^{20}$ phonological erosion is "usually the last to apply in grammaticalization processes, and it is not a requirement for grammaticalization to happen." In other words, phonetic reduction is neither a necessary nor a sufficient property of grammaticalization. Heine and Kuteva emphasized that extension is the central principle among the four interrelated principles: desemanticization, extension, decategorialization, and phonetic erosion..$^{21}$ Regarding the precedence of semantic change, Heine and Kuteva stated that grammaticalization "tends to begin with extension, which triggers desemanticization, and subsequently decategorialization and erosion." Generally, shifts in meaning lead to changes in word type.

It is crucial to note that while desemanticization, decategorialization and erosion of a linguistic item result in a loss in semantic, morphosyntactic, and phonetic substance, extension involves gain in properties characteristic of the uses of the linguistic item in new contexts. ${ }^{22}$ Concurrent with these changes, there is a generalization of grammatical function. That is, grammatical forms tend to be used in a wider range of morphosyntactic functions. For example, the English "going to" at one time referred primarily to movement in space, but "going to/gonna" in future expressions is no longer restricted to that spatial sense.

One of the aspects of language change is the relationship between frequency and the process of grammaticalization. Joan Bybee proposed that as a construction becomes more frequently used, it becomes a distinct, autonomous new construction, and lexical items associated with the construction may become semantically bleached and/or phonologically reduced. ${ }^{23}$ For example,

19 Hopper and Traugott, Grammaticalization, p. 94-98 and 100-106.

20 Heine and Kuteva, The Genesis of Grammar, p. 42.

21 Ibid., p. 35.

22 Ibid., p. 34.

23 Joan Bybee, Frequency of Use and the Organization of Language, Oxford-New York, Oxford University Press, 2007.

This claim is not without problems, for linguistic items with high frequency do not necessarily undergo grammaticalization. Also, it is not unusual for grammaticalization 
the English construction going to [verb] lost the sense of motion and was phonetically reduced to gonna in the course of grammaticalization as a marker of futurity. Joan Bybee and William Pagliuca stated that "as the meaning generalizes and the range of uses widens, the frequency increases and this leads automatically to phonological reduction and perhaps fusion."24 In other words, as the lexical item gains grammatical function, it becomes more abstract.

\section{3}

\section{Data Collection and Analysis}

The data for this study were collected from several sources: field work in Abu Dhabi, Dubai, Fujairah, Ajman, Ras Al-Khaima, and Sharjah, personal communication with native speakers, television series, and interviews and discussions with native speakers of Emirati Arabic. The native speakers with whom I communicated refused to be tape recorded but unhesitatingly provided extensive comments on and explanations of the data. The informants, who were university students from different Emirates, were sometimes invited to verify the authenticity of examples gleaned from TV series, interviews, and shows. ${ }^{25}$ Transcriptions of the material ignored the minimal phonological differences between the sedentary dialect areas of the United Arab Emirates. Instead, a unified representation of words was used to make it easier for readers who are not familiar with the phonological distinctiveness of each of the Emirati dialect areas to recognize words and read the examples provided.

The Emirati Arabic examples of grammaticalization highlighted in this study will be presented briefly since I hope to discuss them in more depth in a future study. In addition, the present study is far from being complete in that

to occur to linguistic items with low frequency. See Sebastian Hoffmann, "Are LowFrequency Complex Prepositions Grammaticalized? On the Limits of Corpus Data and the Importance of Intuition," in Corpus Approaches to Grammaticalization in English, eds Hans Lindquist and Christian Mair, Amsterdam-Philadelphia, John Benjamins ("Studies in corpus linguistics", 13), 2004, p. 171-210; and Lieselotte Brems, "The Grammaticalization of Small Size Nouns: Reconsidering Frequency and Analogy," Journal of English Linguistics, 35/4 (2007), p. 293-324.

24 Joan Bybee and William Pagluica, "Crosslinguistic Comparison and the Development of Grammatical Meaning," in Historical Semantics-Historical Word Formation, ed. Jack Fisiak, The Hague, Mouton ("Trends in linguistics"), 1985, p. 59-83.

25 I would like to express my sincere gratitude to the following native speakers for their help with the data: Nada Alhammadi, Noora Mohamed Alsahi Alzaabi, Amna I. Yousuf Almoosa Alnuaimi, Maitha K. Abdalla Ali Shuhail Alshuhail, Aisha A. Khalifa Ali Falah Alsuwaidi, Sumaiya A. Ahmed Almarzooqi, and Fatima M. Abdulla Ahli. 
the diachronic aspect of the development of these constructions is not taken into account because there is no documentation of these examples in Emirati Arabic. However, on the basis of the findings and generalizations of grammaticalization theory and synchronic evidence from Emirati Arabic, this paper attempts to provide a reconstruction of the step-by-step evolution of the markers.

\section{$4 \quad$ Analysis of Results}

\subsection{Volitional Verb $>$ Future Marker}

In Emirati Arabic, the future is formed by prefixing $b(a)$ - on the imperfect form of the verb. According to Holes, the future particle, which is believed to be a shortened form of the Classical/Standard Arabic lexical verb abgi (I want), has a "modal coloring" which conveys speaker intent. ${ }^{26}$ In 1991, Al-Najjar proposed that the future marker in Kuwaiti Arabic had developed from the lexical verb $a b i$ (I want) which in turn had evolved from the Classical Arabic verb abgi (I want). ${ }^{27}$ In 1967 , Johnstone considered the $b(a)$-prefix to have future meaning with a sense of volition in Kuwaiti, Bahraini and Qatari dialects and is also used to signal future time in the dialects of Abu Dhabi, Dubai, and the Buraimi oasis on the border between the United Arab Emirates and Oman. ${ }^{28}$ Consider the following examples from Emirati Arabic:
(1) Abi a'rris s-sana l-yāyya
I-want I-marry the-year the-coming
"I want to get married next year."

(2) Huwwagāl inna ma yibi-ha He said that NEG want-her "He said that he did not want her."
(3) Idașār mai šayy ba-țtișil fǐk If happen with-me thing FUT-call you "If anything happens, I will call you."

26 Clive Holes, Gulf Arabic, London-New York, Routledge ("Croom Helm descriptive grammars series"), 1990, p. 188.

27 Al-Najjar, "Grammaticalization of Lexical Markers in Kuwaiti Arabic," p. 666-667.

28 Tomas Muir Johnstone, Eastern Arabian Dialect Studies, London, Oxford University Press, 1967 , p. 143, 152, 163, 169 . 


\section{(4) Ba-kammil dirāsti fíamrīka FUT-complete study-my in America "I will complete my study in America."}

As we can see, the lexical verb $(y) a b i$ in examples (1) and (2) expresses desire or intention in the present tense, whereas in (3) and (4) it is reduced to the future marker $b(a)$-. When the verb $(y) a b i$ has reached the stage in which it becomes dependent on another item (i.e. on the verb following it), it has lost its lexical status. Moreover, its lexical content was "bleached" or desemanticized, and, therefore, it has undergone grammaticalization.

But the examples given above do not actually give the whole picture because the $b(a)$ - prefix is used to express other meanings in Gulf Arabic dialects. Maria Persson ${ }^{29}$ argued that not only does the $b(a)$ - prefix encode future tense or intentive mood or a combination of both but also a generalized marking of irrealis mood, which is expressed by a combination of a future marker with a past tense marker to form a conditional. ${ }^{30}$ In his study of the spoken Arabic of the Šarqiyya region of northern Oman, Domenyk Eades also came to the conclusion that the $b(a)$ - prefix is frequently used as a marker of futurity and in "non-future contexts marking meanings of future in the past, condition, and hypotheticality."31

The assumption that the $b(a)$ - prefix that marks the future derives from the verb yab $\bar{g} \bar{a}>y a b \bar{\imath}>y a b \bar{a}>y i b b i>b a>b$ - (want, desire) in Gulf Arabic is supported by the fact that a volitional verb is used to express the future in many Arabic dialects: $b i$-widd $>b a d d>b a-, b i-, b$ - (want) in Levantine varieties, ${ }^{32}$ yaša $\bar{a}^{3}>\check{s} a$ (want) in Yemeni Arabic, ${ }^{33}$ bat, biti, bit, $b a$ - which derive from $b \bar{g} \bar{a}$, $b \bar{g} \bar{a} t, b \bar{g} i t$ (want) in Moroccan Arabic, and $y \bar{a} b a>y i b b i>b a$ - (want) in Libyan. ${ }^{34}$

29 Maria Persson, "The Role of the b-prefix in Gulf Arabic Dialects as a Marker of Future, Intent and/or Irrealis", Journal of Arabic and Islamic Studies, 8 (2008), p. 26-52.

30 Clive Holes, Dialect, Culture and Society in Eastern Arabia, Leiden-Boston-Köln, Brill ("Handbook of oriental studies. Section 1, the Near and Middle East", 51/1), 2000, I [Glossary], p. 34 and 145 .

Domenyk Eades, "Grammaticalization and the Irrealis b-prefix in an Arabic Dialect of Oman," in Grammaticalization in Semitic, ed. Domenyk Eades, Oxford, Oxford University Press (“Journal of Semitic Studies Supplement", 29), 2012, p. 49-66.

Terence Frederick Mitchell and Shāhir El-Hassan, Modality, Mood and Aspect in Spoken Arabic with special reference to Egypt and the Levant, London-New York, Kegan Paul International ("Library of Arabic Linguistics", 11), 1994, p. 19.

33 Kees Versteegh, The Arabic Language, Edinburgh, Edinburgh University Press, 2014, p. 109.

34 Devin J. Stewart, "Clitic Reduction in the Formation of Modal Prefixes in the Post-Classical Arabic Dialects and Classical Arabic Sa-/Sawfa," Arabica, 45 (1998), p. 104-128. For northern 
In some Arabic varieties, especially Levantine Arabic, it is hypothesized that there are two separate $b(a)$ - prefixes, each with its own origin. ${ }^{35}$ That is, the $b(a)$ - prefix that marks the future derives from the verbal noun bi-widd $>$, $b a d d>b a-, b i-, b$ - (want), ${ }^{36}$ whereas the $b(a)$ - prefix that marks the indicative mood, progressive or habitual aspect derives from the preposition $b i$ - (in, by, with). ${ }^{37}$ The assumption that the $b(a)$ - prefix that marks the indicative mood, progressive or habitual aspect derives from the preposition $b i$ - (in, by, with) is supported by the fact that this $b(a)$ - prefix is obligatory in progressive contexts in Egyptian Arabic and Syrian Arabic. ${ }^{38}$ This is further supported by Comrie's assumption that progressive constructions are locative in origin ${ }^{39}$ The progressive use is extended to describe habitual and generic situations (i.e. progressives tend to develop into general imperfects).$^{40}$ In Egyptian Arabic, Ernest $\mathrm{N}$. McCarus stated that when the meaning of the verb is progressive, the indicative mood marker $b i$ - is "obligatory, optional but usual if the meaning is habitual, and usually deleted if the meaning is stative." McCarus added that the spread of the $b(a)$ - prefix to stative verbs in Egyptian Arabic "was relatively recent, and is limited in this usage."41

Further evidence derives from Yemeni varieties, which use $b-, b a-, b i-, b i n-$, bèn-, bìn-, bayn- for expressing progressivity. Following Wolfdietrich Fischer

Omani dialects, see Adrian Brockett, The Spoken Arabic of Khābūra on the Bātina of Oman, Manchester, University of Manchester (“Journal of Semitic Studies Monograph", 7), 1985; and, for Saudi dialects, see Bruce Ingham, Najdi Arabic: Central Arabian, AmsterdamPhiladelphia, John Benjamins ("London oriental and African language library", 1), 1994.

35 For the evolution of the $b(a)$ - prefixes, see Najib Jarad, "The Evolution of the b-Future Marker in Syrian Arabic," Lingua Posnaniensis, 13/1 (2013), p. 69-85.

36 The use of the symbol > is a crude approximation of the assumed development, which cannot be certainly pinpointed because the diachronic clue is lacking. There might be some phonological mechanisms at work.

37 Johnston, Eastern Arabian Dialect Studies, p. 143, 152, 163, 169.

38 See Esseesy, Grammaticalization of Arabic Prepositions and Subordinators, p. 252.

39 Bernard Comrie, Aspect, Cambridge-London-New York, Cambridge University Press ("Cambridge textbooks in linguistics", 2), 1976, p. 103. The $b(a)$ - prefix, which is used to describe progressive aspect, might have originated from the preposition/conjunction baynā which indicates "distance, between, or while" in Classical Arabic. I am grateful to an anonymous reviewer for this point.

$40 \quad$ Bybee, Perkins, and Pagliuca, The Evolution of Grammar, p. 141.

41 Ernest N. McCarus, "A Case of Semantic Reconstruction: The Egyptian Arabic Verbal Prefix Bi," in Studies in Near Eastern Culture and History in Memory of Ernest T. AbdelMassih, ed. James A. Bellamy, Ann Arbor, Center for Near Eastern and North African Studies-The University of Michigan ("Michigan series on the Middle East", 2), 1990, p. 104. 
and Otto Jastrow, ${ }^{42}$ Stewart suggested that these forms derive from the Classical Arabic baynamā (while) or its variant bayna.$^{43}$

In a nutshell, the verb $(y) a b i$, originally a verb meaning "want, desire," has gradually developed into a grammatical particle expressing volition and future. As this lexical verb becomes grammaticalized, it is reduced to an affix. Furthermore, the frequency with which the affix is used in addition to its contiguity to the verb stem has led to its eventual fusion with the verb.

\subsection{Noun $>$ Subordinate Conjunction}

Semantically, in addition to its primary lexical meaning (day, time), yōm also serves as a subordinate conjunction introducing time clauses. This means that yōm as a subordinate conjunction has undergone semantic bleaching. As a lexical item, yōm has a dual form yōmēn (two days) and a plural form ayyām (days).

\section{(5) a. Țarriša l-yōm \\ Send-it the-day \\ "Send it today."}

b. Hams marrāt fì l-yōm

Five times in the-day

"Five times a day."

c. A-šūf-ak mbačir l-yōm

I-see-you early the-day

"I see that you came early today."

d. Bigi hni yōmēn

remained-he here day-two

"He stayed here two days."

e. Mafì 'amn hal'ayyām

NEG-in security these days

"There is no security these days."

42 Wolfdietrich Fischer and Otto Jastrow (eds), Handbuch der arabischen Dialekte, Wiesbaden, Otto Harrassowitz ("Porta linguarum orientalium. Neue serie", 16), 1980, p. 74.

43 See also Aaron D. Rubin, Studies in Semitic Grammaticalization, Winona Lake, Eisenbrauns. (“Harvard Semitic Studies", 57), 2005, p. 146. 
However, the noun yōm has developed into an adverbial subordinate clause conjunction meaning "when, while."

(6) a. Yōm sima' l-habar yilas yi-șịh

When heard-he the-news sat-he he-weep

"When he heard the news, he started to weep/he sat weeping."

b. Ṭāh 'ala-l-ard yōm kān yi-ḥāwil yi-rkab s-sīkil

Fell-he on the-ground when was he-try he-ride the bicycle "He fell down to the ground when he was trying to ride the bicycle."

c. Kint yālis i-dris yōm 'omarfarr l-hasasa

Was-I PROG I-study when Omar threw the-stone ' $a$ - $d$-drǐša

on the-window

"I was studying when Omar threw the stone against the window."

d. Yōm raddșulțān l-bēt nurakānat yālsa

When returned Sultan the house Nora was-she PROG ti-dris

she-study

"When Sultan came home, Nora was studying."

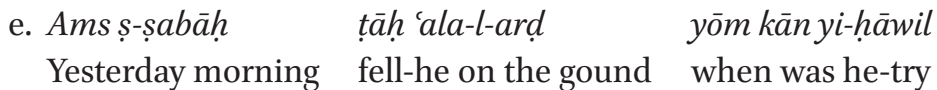

yi-rkab s-sikil

he-ride the bicycle

"Yesterday morning, he fell down to the ground when he was trying to ride the bicycle."

In these particular examples, the noun yōm has been reinterpreted as an adverbial subordinator in a subordinate temporal clause, following a universal grammaticalization path TIME > TEMPORAL. ${ }^{44}$ The compatibility of $y \bar{o} m$ with a temporal adverb like ams ș-șabāh (yesterday morning) in (6) shows that yōm has clearly lost its lexical content in Emirati Arabic. ${ }^{45}$

44 Heine and Kuteva, World Lexicon of Grammaticalization, p. 298-299.

45 I am grateful to an anonymous reviewer for raising the question of the possibility of using a temporal adverb with yōm. 


\subsection{Noun $>$ Reflexive Pronoun}

A reflexive marker typically denotes a referent that is identical with the one of the subject noun phrase. Generally, the reflexive marker has the syntactic function of an object, as in (12):

(7) a. John hurt himself.

b. The children dressed themselves.

c. The CEO paid himself a huge salary.

Cross-linguistically, reflexive pronouns evolve from several sources: body part names, nominal sources denoting something like person, self, owner, emphatic pronouns, object personal pronouns, locative prepositions, etc. ${ }^{46}$

The Classical Arabic nouns nafs (soul) and rūh (soul) have evolved into a reflexive pronoun in Emirati Arabic and some other spoken varieties as well. ${ }^{47}$ The examples in (8) show rüh (soul) used as a noun whereas the ones in (9) show rūh (soul) used as a reflexive pronoun.

(8) a. Allah yi-gammid rūḥ-a l-yanna

God He-protect soul-his the-paradise

"May God rest his soul in paradise?"

b. Nifd-i 'imārāt-na b-'arwāḥ-na

Sacrifice-we Emirates-our with-souls-our

"We sacrifice our souls for our Emirates."

(9) a. Sāfart landon b-rūḥi

Travelled-I London by-REFLEX

"I travelled to London by myself."

b. Yaddat-i ‘āyša b-rūḥha

Grandmother-my living by-REFLEX

"My grandmother lives alone or by herself."

46 See Mathias Schladt, "The Typology and Grammaticalization of Reflexives," in Reflexives: Forms and Functions, eds Zygmunt Frajzyngier and Traci S. Curl, Amsterdam-Philadelphia, J. Benjamins ("Typological studies in language", 40), 2000, p. 102-124.

47 Holes, Gulf Arabic, p. 166; Rubin, Studies in Semitic Grammaticalization, p. 19. 
The grammaticalization process of $r u \bar{h}$ (soul) can be summarized as follows: (i) rūh (soul) is used in new contexts, (ii) undergoes gradual loss of original lexical meaning, and (iii) loses its nominal status and becomes a reflexive pronoun.

\subsection{Noun >Possessive Exponent}

Possessive relations can be expressed by three types of construction, either (i) a synthetic construction (Arabic idäfa), (ii) a preposition + pronoun suffix construction, or (iii) as an analytic possessive construction with a possessive exponent or connector. ${ }^{48}$ The choice of the synthetic possessive over the analytic construction has to do with a set of inalienable nouns which includes kinship terms (e.g. mother, father, uncle, etc.) and body part terms (e.g. head, foot, arm, stomach, etc.). In addition, the choice between the synthetic, for example lahmi (my flesh) and the analytic construction il-lahm bitāi i "meat that belongs to me [e.g. that I bought]," according to Janet Watson, "may at any one time be due to formal reasons to avoid the complexity and ambiguity of the synthetic genitive, or to stylistic and/or rhythmic factors." ${ }^{\text {99 }}$ The synthetic possessive, also known traditionally as the construct state, is a possessive construction in which the "possessed" and the "possessor" are juxtaposed [possessedpossessor], as in ktāa șulțān (sultan's book), or the possessor is represented by a pronoun suffixed to the possessed element, as in $k t a \bar{b}$ - $h a$ (her book).

The common prepositions that can show possession are 'and (with, by, at);

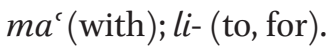

$\begin{array}{cll}\text { (10) a. 'Ind-ì sayyāra yidìda } \\ \text { To-me car } & \text { new }\end{array}$

"I have a new car."

48 The synthetic genitive is also known in the literature as inalienable (i.e. a construction used with kinship and/or body part terms) while the analytic genitive is known as alienable (i.e. a construction not used with kinship and/or body part terms). See Kristen Brustad, The Syntax of Spoken Arabic: a comparative study of Moroccan, Egyptian, Syrian, and Kuwaiti dialects, Washington, Georgetown University Press, 2000, p. 70; and Östen Dahl and Maria Koptjevskaja-Tamm, "Alienability splits and the grammaticalization of possessive constructions," in Papers from the 16th Scandinavian Conference of Linguistics, ed. Timo Haukioja, Turku, University of Turku ("Turun yliopiston suomalaisen ja yleisen kielitieteen laitoksen julkaisuja", 6o), 1998, p. 38-94.

49 Janet Watson, "Arabic Dialects," in The Semitic Languages: An International Handbook, ed Stefan Weninger, Berlin-Boston, De Gruyter-Mouton ("Handbooks of linguistics and communication science", 36), 2011, p. 864. 
b. L-walad li-'abūh
The-boy to-father

"Like father like son/the son belongs to his father."

c. Ma'a flūs wāyid
With-him money much
"He has a lot of money."

The third type is the analytic possessive construction, which makes use of a possessive exponent or connector to express that relationship. Most modern spoken varieties of Arabic have developed possessive exponents or connectors, which are particles that are used under certain conditions for an analytic linking of two nouns or a noun and a pronoun suffix instead of a direct annexation. Diachronically, most of these particles originated from a word meaning "right, property" or "wealth, property." Kerstin Eksell Harning provided an extensive survey of possessive constructions in spoken Arabic varieties. ${ }^{50}$ Here are some examples:
(11) Syrian Arabic
tabac
Lebanese Arabic
tabac
Egyptian Arabic
bitā̄
Iraqi Arabic (Baghdad) $m \bar{a} l$
Sudanese Arabic
hagg/hagg
Yemeni Arabic
haqq/hagg
Omani Arabic
$m \bar{a} l / h a g g$

In these spoken varieties, the synthetic coexists with the analytic possessive constructions, which differ from one variety to another. The choice of the genitive construction is in some cases obligatory, due to semantic constraints. For example, the analytic possessive construction is not used with terms of kinship or parts of the body, as in:
(12) a. *Hāl māli/haggi (analytic possessive)
Uncle poss
"My maternal uncle."

\footnotetext{
5o Kerstin Eksell Harning, The Analytic Genitive in the Modern Arabic Dialects, Göteborg, Göteborgs universitet (“Orientalia gothoburgensia”, 5), 1980.
} 
b. *Ayn māli/ḥaggi

Eye Poss

"My eye."

c. Huăl-i (synthetic genitive)

Uncle-my

"My maternal uncle."

d. 'Ayn-i

Eye-my

"My eye."

Speakers of Emirati Arabic frequently use the possessive exponents, hagg (right, property) or $m \bar{a} l$, (wealth, property), instead of a true synthetic construction to show possession or belonging. The structure of the analytic possessive construction consists of [possessed + hagg $/ \mathrm{ma} l+$ possessor] . According to Hamdi A. Qafisheh, hagg is usually used with animate or inanimate nouns while $m \bar{a} l$ is used with inanimate nouns, especially appliances, spare parts, etc. This observation is borne out by the following examples: ${ }^{51}$

(13) a. L-ktāb hagg l-walad

The-book poss the-boy

"The boy's book."

b. S-sayyāra hagg d-dīwwān l-'amìri

The-car poss the-court the Emiri

"The car belongs to the Emiri Court."
c. L-lisan hagg l-drēwil
The-license poss the-driver
"The driver's license."

(14) a. L-jaw māl hal'iyyām hārrwāyid

The-weather poss these days hot too

"The weather is too hot these days."

51 Hamdi A. Qafisheh, A Short Reference Grammar of Gulf Arabic, Tucson, The University of Arizona Press, 1977, p. 117. 
b. L-brēkāt māl s-sayyāra yidìda The-breaks poss the-car new

"The car brakes are new."

c. Yōm šayy mob māl-ak ma y-ḩșsak -tihibša When thing NEG POSs-yours NEG you-concern-touch "When something is not yours, do not touch it."

d. $D$-dūbi 'aț-ni gitra mobmāl-i

The-launderer gave-me headcloth NEG POss-my

"The launderer gave me a headcloth which did not belong to me."

In the above examples, the lexical item indicating "possession, property" has undergone a degree of semantic bleaching and subsequently acquired the additional grammatical function of indicating possessive relationships between nouns or NPs. Therefore, in Emirati Arabic, the lexical forms hagg (right, property) and $m \bar{a} l$ (wealth, property) have acquired this possessive function, which corresponds closely to the cline PROPERTY (property, possession) > A-POSSESSIVE. ${ }^{52}$ What is common to all varieties of spoken Arabic is that the lexical item used in an analytic construction has undergone a degree of semantic bleaching, and subsequently acquired the additional grammatical function of indicating possessive relationships between nouns or noun phrases..$^{53}$

\section{$5 \quad$ Concluding Remarks}

This paper has attempted to present analyses of selected Emirati Arabic grammaticalizations in the light of grammaticalization concepts and mechanisms of language change. It has been shown that Emirati Arabic offers a wealth of linguistic materials which can be topics for further developmental research. The examples investigated in this study verify the theoretical tenets of grammaticalization in two ways. First, when a lexical item moves toward grammaticalization, its original form may remain as an autonomous lexical element. This kind of situation, where two homophonous words exist side by side, one

$5^{2}$ Heine and Kuteva, World Lexicon of Grammaticalization, p. 245-246.

53 See Harning, The Analytic Genitive in the Modern Arabic Dialects; Brustad, The Syntax of Spoken Arabic; and Watson, "Arabic Dialects," among many others. 
functioning as a lexical category and the other as a grammatical one, is what has been described as "divergence" by Hopper and Traugott. ${ }^{54}$ This amounts to saying that grammaticalization of a form does not result in the elimination of old forms. Second, these examples reflect universal linguistic tendencies and provide an excellent starting point for a more comprehensive investigation.

54 Hopper and Traugott, Grammaticalization, p. $114 \mathrm{ff}$. 